IZA DP No. 8561

The Labor Supply of Self-Employed Workers:

The Choice of Working Hours in Worker Co-ops

John Pencavel

October 2014 


\title{
The Labor Supply of Self-Employed Workers: The Choice of Working Hours in Worker Co-ops
}

\author{
John Pencavel \\ Stanford University \\ and IZA
}

\section{Discussion Paper No. 8561 \\ October 2014}

\author{
IZA \\ P.O. Box 7240 \\ 53072 Bonn \\ Germany \\ Phone: +49-228-3894-0 \\ Fax: +49-228-3894-180 \\ E-mail: iza@iza.org
}

\begin{abstract}
Any opinions expressed here are those of the author(s) and not those of IZA. Research published in this series may include views on policy, but the institute itself takes no institutional policy positions. The IZA research network is committed to the IZA Guiding Principles of Research Integrity.

The Institute for the Study of Labor (IZA) in Bonn is a local and virtual international research center and a place of communication between science, politics and business. IZA is an independent nonprofit organization supported by Deutsche Post Foundation. The center is associated with the University of Bonn and offers a stimulating research environment through its international network, workshops and conferences, data service, project support, research visits and doctoral program. IZA engages in (i) original and internationally competitive research in all fields of labor economics, (ii) development of policy concepts, and (iii) dissemination of research results and concepts to the interested public.
\end{abstract}

IZA Discussion Papers often represent preliminary work and are circulated to encourage discussion. Citation of such a paper should account for its provisional character. A revised version may be available directly from the author. 
IZA Discussion Paper No. 8561

October 2014

\section{ABSTRACT}

\section{The Labor Supply of Self-Employed Workers: The Choice of Working Hours in Worker Co-ops}

Workers in cooperatives are self-employed workers and, if they resemble employees in conventional workplaces, they care about the length of their working hours. In this paper, their choice of hours is characterized as a conventional labor supply decision and a familiar hours-wage relationship is derived. This is estimated using mill-year observations on the plywood co-ops in the Pacific Northwest. The results are compared with those from the work behavior of other self-employed workers and with working hours in capitalist plywood mills.

JEL Classification: J22, J54

Keywords: labor supply, hours, worker co-ops

Corresponding author:

John Pencavel

Department of Economics

Stanford University

Stanford, CA 94305-6072

USA

E-mail: pencavel@stanford.edu 


\title{
THE LABOR SUPPLY OF SELF-EMPLOYED WORKERS:
}

THE CHOICE OF WORKING HOURS IN WORKER CO-OPS

\author{
John Pencavel*
}

\section{INTRODUCTION}

This article contributes to two literatures in economics. The first is the research on the supply of labor that focuses on the responsiveness of hours of work to wages. There is a huge body of work on this topic (Keane (2011)) prompted in part by the important public policy question of how revenue from income taxes will change when income tax rates change. In view of the fact that more than forty percent of Federal tax revenue derives from income taxes, the importance of knowing how income tax rates affect work hours and tax revenues is clear. The research on this topic will be drawn upon selectively to contrast the empirical results here with earlier findings.

The second literature touched on in this article relates to the behavior of worker cooperatives, that is, enterprises owned and managed by those who work in them. The case for and against such enterprises has been debated for many decades and this exchange is enriched when evidence can be provided on their actual operations. The orthodox characterization in economics of the behavior of the worker co-op is that it maximizes the net returns per member-worker. This monetary objective was proposed by Ward (1958) to contrast it with the profit maximization goal of the capitalist enterprise that is owned and managed (often indirectly) by the supplier of capital. A more general objective is offered here for the worker co-op, one that follows Scitovsky's (1943) amendment of profit maximization that endows the capitalist entrepreneur with a utility function in which both monetary returns and working hours are arguments. Analogously, allowing the co-op to trade-off income for working hours implies a labor supply decision for the co-op workers and this trade-off is estimated below.

As the co-op is a group of self-employed workers, all of whom work the same number of hours and earn the same hourly returns, their estimated labor supply behavior may be compared with that estimated for other self-employed individuals. If the hours of workers in co-ops are unrelated to their

\footnotetext{
${ }^{*}$ Research assistance from Monica Bhole is gratefully acknowledged. The work reported in this paper formed the basis of a presentation at the Conference of the International Association for the Economics of Participation (IAFEP) in July 2014. I benefitted from comments of the participants at this conference and from two anonymous referees. The data used in this article are available in the appendix to the paper at http://siepr.stanford.edu/?q=/system/files/shared/pubs/papers/13-036.pdf .
} 
work incentives, Ward's maximand - net monetary returns per member-worker - is sustained.

The worker co-ops to be examined are those engaged in plywood production in the Pacific Northwest between 1968 and 1986. In the twentieth century, these enterprises constituted the most substantial worker-owned and worker-managed sector in United States manufacturing industry. After providing a brief description of these worker co-ops, the model will be outlined and then fitted to observations on these enterprises. On the assumption that the resulting hours-wage relationship reflects the preferences of plywood workers, the hours worked in co-ops are compared with the hours worked by employees in a conventional (capitalist) plywood mill. This comparison leads to the inference that hours are shorter in the capitalist mill than those preferred by plywood workers, a consequence of the higher wages that discourage the typical capitalist mill from selecting hours that workers prefer. In short, in the capitalist mill, the hours-wage relationship expresses the preferences of the owners or managers, not those of the workers.

\section{THE PLYWOOD MILLS OF THE PACIFIC NORTHWEST}

The establishment of the Olympia Veneer Company in 1921 is usually taken to represent the birth of the worker cooperatives in the plywood industry of the Pacific Northwest. It served as the paradigm for the worker-owned and worker-managed enterprises that were established in subsequent decades in the plywood industry. In the 1950s, almost one hundred percent of U.S. softwood plywood was produced in the Pacific Northwest and between one-quarter and one-fifth of that was made in the co-ops (Berman (1967), p.93). After that time, the importance of the Northwest in the U.S. production of plywood declined because of depletion of its old timber forests, environmental restrictions on logging, and the subsequent rising cost of logs. The use of southern pine for plywood allowed the South to displace the Northwest as the major region of plywood production in the U.S. ${ }^{1}$ See Figure 1. So, with the empirical analysis restricted to mills producing plywood between 1968 and 1986, this is a study of firms in a declining industry in this location. As the industry contracted in the Pacific Northwest so many co-ops closed; some converted to conventional forms of organization. Whereas

\footnotetext{
1 "The total wood cost in the South is slightly less than in Oregon and Washington. Most of this difference is due to lower logging and hauling costs. The terrain in the South is much gentler than that in western Oregon and Washington, so all logging can be done by tractors/skidders." Oregon Forest Resources Institute (2012, p.70).
} 
Berman (1967) surveyed 24 plywood co-ops in the Pacific Northwest in 1964, at the time of writing, I am able to confirm only one of them still operating in Washington state. ${ }^{2}$

The research reported below relies upon 55 mill-year observations on eleven co-op mills in even-numbered years between 1968 and 1986. The set of observations is not balanced. The identity of the co-ops examined here are listed in Table 1 together with the dates of their birth and, if known, the dates of their demise. All these plywood co-ops were in Washington state. ${ }^{3}$ Other information on these co-ops is supplied in Table 1 including their size and their capital equipment. By no means were these co-ops all the same and this will be recognized in the equations fitted below that allow for fixed differences among them.

The plywood co-ops conformed to the Rochdale principles that define the cooperative enterprise. All co-op members were workers in the enterprise and most workers (often, all workers) were members. Membership in a plywood co-op required the acquisition of a share and a probationary period of employment. The co-op member-workers were often referred to simply as "shareholders". One method for the exchange of shares was through the Business Opportunities section of the Portland Oregonian and an analysis of the prices of these shares is contained in Craig and Pencavel (1992) where it is shown that prices for these shares moved with the fortunes of the plywood industry. They also differed noticeably across the co-ops. Regrettably, these share prices could not be obtained for the Washington co-ops under study here. ${ }^{4}$

Each member had one vote in the co-op's decisions in selecting the directors from among the

\footnotetext{
${ }^{2}$ This is Hardel Mutual Plywood in Chehalis which was described by another plant's manager as "still going strong".

${ }^{3}$ A number of plywood co-ops operated in Oregon and at least two in northern California, but the state of Washington conducted a survey of plywood mills every two years and this provided information on the output and raw material inputs of these mills. Oregon's mills contributed to the study of the co-ops' share prices (Craig and Pencavel (1992)), but information is lacking on their hours of work.

4 "Regrettably" because the equation that is fitted below is interpreted as a labor supply equation, but as such it omits variations in non-labor income. A co-op worker's principal asset was his share in the company in which he worked and movements in the price of his share would serve as an indicator of variations in his wealth. Insofar as movements in the prices of shares are correlated with variations in the prices of log inputs and of plywood output, the addition of these variables to the equation fitted below leaves the negative coefficient on wages almost the same. This is evident from the estimates reported in Table 6 of Craig and Pencavel (1992).
} 
workers. The turnover of directors was high. In a co-op mill at a given moment, each worker received the same hourly pay, the amount incorporating any dividends on common stock although, on the principle of only rewarding labor not capital, some co-ops prohibited the payment of dividends. Also, each worker worked the same number of hours. ${ }^{5}$

The principal constraints on each plywood mill were the price of its major input, logs, and the price of its output, plywood, both being beyond the control of any single mill. Most logs came from Federal and state forests and were sold at public auctions. Plywood is bought and sold on international markets and, in recent years, imports from east Asia have prompted calls from native plywood producers for protection. Log and plywood prices are volatile because the demand for plywood varies with home and office construction which is highly cyclical. Because mills used different varieties of wood, log and plywood prices varied across mills but much of the variation in these prices is over time. ${ }^{6}$ Consequently, the wage paid out of net receipts to the co-op workers also varies with movements in the prices of logs and the prices of plywood. Illustrative of this is the following estimated regression equation which uses the 55 mill-year observations described below on the co-ops to relate the logarithm of the real hourly wage of co-op workers, $\ln \left(w_{i t}\right)$ to the logarithm of real log prices $\ln \left(r_{i t}\right)$ and the logarithm of real plywood prices $\ln \left(p_{i t}\right)$ controlling for fixed mill effects, $v_{i}$ :

$$
\ln \left(w_{i t}\right)=v(i)+0.942 \ln \left(p_{i t}\right)-0.252 \ln \left(r_{i t}\right)
$$

where heteroskedastic-consistent standard errors are in parentheses and the $R^{2}$ statistic is 0.577 . A mill is denoted by $i$ and a year by $t$. Without the mill fixed effects, variations in $\ln \left(p_{i t}\right)$ and $\ln \left(r_{i t}\right)$ remove only 14 percent of the variation in $\ln \left(w_{i t}\right)$.

\footnotetext{
5 "Since the income a shareholder receives is based entirely on hours of work performed, equalization of hours worked and of overtime for all shareholders is carefully safeguarded so far as possible. Records are kept of time worked, and extra work is allotted to men who have worked fewer hours. Conversely, if a man has built up a total of hours of work too far above that of others, he may be forced to take a few days off." (Berman (1967, p. 153)

${ }^{6}$ Thus, for the 55 mill-year observations on co-op mills that are used below, 93.6 percent of the variation in the logarithm of log prices and 40.9 percent of the variation in the logarithm of plywood prices are removed by fixed year effects alone.
} 
In the same industry, in the same region, and at the same time, conventional plywood mills operated, conventional in the sense that the workers were supervised by managers hired by those who did not work in the mill and who supplied the capital. The production workers in most of these conventional plywood mills were covered by collective bargaining contracts although a few mills were non-union. The non-union mills tended to be small and they operated intermittently. The co-op mills and the conventional unionized mills were of comparable size and operated both in prosperous years and in years when plywood prices were low. There was little difference between the co-ops and the capitalist mills in the type of work involved: it was dirty, noisy, and dangerous that required much heavy lifting although there were opportunities for superior performance through workers' expertise and good judgment. ${ }^{7}$

The presence of these conventional mills permits the reactions of the co-ops to changes in their price environment to be compared with the reactions of the conventional mills to these changes and this has been the subject of previous research. 102 mill-year observations on nineteen unionized mills are used below to compare with the co-op mills. Earlier research has reported that these plywood co-ops respond to shocks in input (log) prices and to output (plywood) prices by adjusting their wages, rather than by changing employment whereas the corresponding adjustments in the capitalist plywood mills tend to take the form of changing input and output quantities including employment. ${ }^{8}$

Along several dimensions, the workers within each plywood co-op were homogeneous and, moreover, procedures were adopted that cultivated such homogeneity: virtually all the workers were men, ${ }^{9}$ jobs were rotated, and hourly pay and work hours were the same for all workers. Attendance at mill-wide meetings was usually high and member-workers were involved deeply in plant decisions. The similarity of workers eased decision-making and workers were more inclined to carry out decisions they helped to determine. In addition, the problems in formulating and executing the goals of an organization are less formidable when the individuals have similar values and are treated in a like manner. This similarity of the workers within the co-op makes the model-building exercise below more plausible than in other situations involving groups of individuals because the model neglects differences

\footnotetext{
${ }^{7}$ See, for example, Berman's account (1967, pp. 43-50).

${ }^{8}$ See Craig and Pencavel (1992) and Pencavel and Craig (1994).

${ }^{9}$ Gunn (1980, p. 395) reports a few non-shareholding women in office jobs.
} 
among the workers within the enterprise. Consider now the determination of work hours in the co-ops.

\section{HOURS OF WORK IN THE WORKER CO-OPS}

First, did variations in working hours make a difference to the operations of co-ops? One simple way to answer this is to fit production functions to co-ops and ask whether variations in hours of work affected output and, indeed, whether these effects of hours differed from the effects on output of differences in the number of workers employed. That is, a common specification for estimating production functions combines hours of work per worker, $H$, and employment, $E$, into a single variable: worker-hours, the product of the number of workers and average hours of work. ${ }^{10}$ With a CobbDouglas production function, this implies a specification of the following sort:

$$
\ln (X)_{i t}=\alpha_{0}+\alpha_{1} \ln (\text { E.H })_{i t}+\alpha_{2}(\text { other inputs })_{i t}+\varepsilon_{1 i t}
$$

But this equation implies that a given proportional change in employment has the same effect on output $(X)$ as the same proportional change in hours per worker. The effects of differences in hours on output may be distinguished from those of employment on output by fitting

$$
\ln (X)_{i t}=\beta_{0}+\beta_{1} \ln (H)_{i t}+\beta_{2} \ln (E)_{i t}+\beta_{3}(\text { other inputs })_{i t}+\varepsilon_{2 i t}
$$

When equations (2) and (3) are fitted by least-squares to the mill-year observations on the plywood coops in the Pacific Northwest, the estimates of the key parameters are

$$
\begin{array}{crr}
\alpha_{1}=0.507 & \beta_{1}=0.431 & \beta_{2}=0.674 \\
(0.179) & (0.209) & (0.402)
\end{array}
$$

A given percent increase in working hours has a smaller effect on output than the same percent increase in employment, but variations in hours of work matter for production. ${ }^{11}$ The model below is designed to determine the basis for these variations in working hours. In these data, although there are no

\footnotetext{
${ }^{10}$ Of course, another strategy in estimating production functions is to measure labor by the number of workers alone and to ignore hours of work as Defourny et al. (1992), Fakhfakh et al. (2012), and Jones (2006) appear to do in their research on the production functions of worker co-ops.

${ }^{11}$ These production functions also include the logarithm of the inputs of raw material logs, a measure of capital, mill fixed effects, and year fixed effects. Robust standard errors are in parentheses.
} 
variations in hours worked among the workers within each co-op, there are variations in hours worked across co-op mills in a given year and also variations in hours worked across years for each and every co-op mill. To account for these variations, the conventional model of labor supply is drawn upon to describe movements and differences in working hours in terms of variations in workers' returns to work.

Ward (1958) suggested that the behavior of the co-op be understood as selecting its inputs to maximize net returns to each member-worker. In his simplest version, there is only one variable input, the number of member-workers, $E$, and net returns per worker are distributed in the form of per worker wages, $w$, expressed as

$$
w=\frac{p X(E)-C}{E}
$$

Output is given by $X, p$ is the price per unit of output, and $C$ represents fixed costs. Ward's graphical representation is reproduced in Figure 2 where the curve $v v^{\prime}$ equals the gap between gross revenues and costs divided equally among the workers. The employment that maximizes $w$ is $E_{o}$ in Figure 2.

Ward did not overlook hours worked per worker. He assumed explicitly that he was neglecting hours of work "........to avoid introducing the marginal disutility of labor as an important constraint". To represent Ward's explanation graphically, suppose employment is fixed. This was not precisely the case in the plywood coops, but employment varied little over time. The number of member-workers was a long-term decision for each co-op and short-term adjustments in labor took the form of variations in hours per worker, $H^{12}$ Recognizing the role of working hours and reinterpreting $w$ as monetary returns per worker per hour, the specification of the hourly returns to each member-worker $w$ becomes

$$
w=\frac{p X(E, H)-C}{E \cdot H}
$$

Equation (4) is the appropriate description of how net returns to plywood co-op member-workers were

\footnotetext{
${ }^{12}$ A more general model would allow a co-op to react to changes in its economic environment by choosing between adjustments in hours per worker and in the number of workers. Because employment varied little in the plywood co-ops, this generalization is not pursued here. If a co-op's preferences were extended to cover employment, the approach used by Burdín and Dean (2012) might be fruitful.
} 
allocated: they were distributed among workers according to their hours of work. Figure 3 assumes employment is fixed and replaces the number of member-workers on the horizontal axis with the hours worked by each member-worker. $w$ is now related to hours of work as in equation (4). The hours that maximize per worker-hour monetary returns are $H_{O}$.

Now add indifference curves between income and working hours in Figure 3. Given the monetary returns to a worker as expressed by the curve $v v^{\prime}$, the hours that maximize the well-being of co-op workers are $H_{1}$, hours at which take-home pay is lower than at $H_{O}$. In Ward's language, preferences over working hours constrain the selection of the hours that maximize monetary returns. If co-op workers did not care about the length of their working hours and maximized hourly monetary returns, the indifference map in Figure 3 would consist of a series of horizontal lines with the highest attainable indifference curve tangent to $v v^{\prime}$ at $H_{0}$. To ascertain how the representation in Figure 3 of the worker co-op's behavior accords with the observations of the Pacific Northwest plywood co-ops, preferences over pay relative to working hours will be assumed given but variations over time and across mills in the slope of $v v^{\prime}$ will allow the work-income preferences of the member-workers to be identified.

Suppose a co-op's utility function is given by $U=f(H, y)$ where $H$ is each worker-member's working hours and $y$ is each worker-member's income from work in the co-op. ${ }^{13}$ The marginal utility from income is assumed positive and diminishing while marginal utility from hours of work is negative and diminishing. The co-op worker's income is $y=w . H$, the product of his hours of work, $H$, and his hourly earnings, $w$, as specified in equation (4). It is evident from equation (4) and from Figure 3 that $w$ varies with $H$ and, if hours are less than those at which earnings are a maximum, increases in $H$ raise $w$. An expression describing this relationship between changes in $H$ and the changes in $w$ along $v v^{\prime}$ in Figure 3 in the neighborhood of $e$ is

\footnotetext{
${ }^{13}$ From their careful examination of the plywood co-ops, Berman and Berman (1978, p. 703) added hours per worker to a co-op's objective function and wrote, "The ability of the firm to control and vary hours of work to adjust the labor input should be considered an integral part of worker-managers' decision-making authority". Berman (1977) recognizes the relevance of hours of work to a co-op and he endows each co-op member-worker with a utility function defined over labor income and hours of work. Towards the end of his article, Berman acknowledges that there are no differences among workers in work hours in a single plywood co-op. In this article, instead of a single worker being endowed with a utility function over earnings and hours, each co-op is endowed with such an objective function.
} 


$$
w=g(H)=A H^{\theta}
$$

If the relationship between $w$ and $H$ resembles $v v^{\prime}$ in Figure 3, then, around $e, A>0$ and $0<\theta<1 .{ }^{14}$ The choice of work hours that maximize the coop's utility function subject to equation (5) satisfies

$$
-\frac{\delta f}{\delta H}=\lambda \frac{d y}{d H}=\lambda\left(w+H \frac{d g}{d H}\right)=\lambda w(1+\theta)
$$

where $\lambda=\partial f / \partial y$ and $d g / d H=A \theta H^{\theta-1}=\theta w H^{-1} \cdot{ }^{15}$

For the coop's utility function, assume it takes the form of Houthakker's (1959) addilog:

$$
U=f(H, y)=-B H^{\gamma}+\psi(y)
$$

where $\gamma=w H>0$ and $\psi$ is increasing in $y$. In this case, equation (6) becomes

$$
B \gamma H^{\gamma-1}=\lambda w(1+\theta)
$$

Upon taking logarithms,

$$
\ln H=(\gamma-1)^{-1}[\ln \lambda+\ln (1+\theta)-\ln (B)-\ln \gamma]+(\gamma-1)^{-1} \ln (w)
$$

Rearranging this equation and identifying what is assumed to vary across mills by the subscript $i$ and what is assumed to vary over years by the subscript $t$,

$$
\ln H_{i t}=c+v_{i}+\delta \ln \left(w_{i t}\right)+\varepsilon_{i t}
$$

where $\delta=(\gamma-1)^{-1}, c=\delta \ln \left(\lambda B^{-1} \gamma^{-1}\right)$, and $v_{I}+\varepsilon_{i t}=\delta \ln \left(1+\theta_{i t}\right) . v_{\mathrm{i}}$ represents fixed mill effects and $\varepsilon_{i t}$ is a random disturbance. Note that, in accordance with the earlier characterization of this procedure, the co-op's work-income preferences (embodied in $\gamma, B$, and $\lambda$ ) are assumed constant across mills and years while the wage-hours opportunities (expressed by $\theta$ and $w$ ) are assumed to differ over

\footnotetext{
${ }^{14}$ At a point such as $e$ in Figure 3, $p E^{-1}(d X / d H)>w$ or the per worker value of the marginal product of hours exceeds hourly wages .

${ }^{15}$ Second-order conditions involve the properties of the $v v^{\prime}$ curve in Figure 3 in addition to those of the utility function.
} 
time and across mills. Evidently, in equation (8), with other things constant, the (uncompensated) elasticity of working hours with respect to wages is $\delta=(\gamma-1)^{-1}$ which may be positive or negative so that a dominant substitution effect or a dominant income effect is possible. Equation (8) is the starting point for estimation although restricted and augmented versions will be reported. Consider now the observations on the plywood co-ops that will be used to estimate $\delta$ in equation (8).

\section{ESTIMATING THE WORKERS' WORK-INCOME PREFERENCES}

Hours and Wages of Plywood Workers

Descriptive statistics on annual hours of work and real hourly wages (in 1967 dollars) on the co-op plywood mills ${ }^{16}$ and, to provide a comparison, on the conventional unionized mills are provided in Table 2. There are 55 mill-year observations on eleven co-op mills and 102 observations on nineteen conventional unionized mills. At all points of the distribution of working hours in Table 2, the value for working hours in the co-ops exceeds the value for hours in the conventional unionized mills. ${ }^{17}$ As is well known (Carrington, McCue, and Pierce (1996)), the self-employed tend to work longer hours than employees. In the case of the co-op workers, do they work longer hours because they shape their work environment and, as a consequence, are less averse to work than employees whose control over their workplace is more circumscribed? Or is the difference between the hours of co-ops and the hours of capitalist mills a reflection of self-selection: those workers who are less work shy are attracted to a cooperative enterprise? ${ }^{18}$

Because the co-op selects its monetary distributions to its member-workers as well as its working hours, it may be important to recognize this endogeneity in estimation and, where possible,

\footnotetext{
${ }^{16}$ The observations on hourly wages were not constructed by a researcher dividing net revenues per worker by hours worked. They are taken from the records of the mills themselves and represent average values over the year.

${ }^{17}$ Moreover, hours in the co-ops are right-skewed while those in the conventional mills left-skewed.

${ }^{18}$ The observations on co-op plywood mills are not distributed across years in the same way as our observations on conventional mills. Therefore, it may be important to control for this difference in computing the difference across mills in annual working hours. When this is done, workers in co-op mills work 33 percent more hours than workers in the conventional mills. The gap between hours in co-ops and those in non-union mills is even greater: 56 percent which reflects the fact that these nonunion mills often operated for only part of the year.
} 
this is done by using variations in the logarithmic price of output and in the logarithmic price of logs as instrumental variables for $\ln \left(w_{i t}\right) .{ }^{19}$ These output and input prices are beyond the influence of any mill and they are the fundamental predetermined variables to which all mills, co-ops and conventional mills alike, must respond. However, they are weak instruments: variations in the logarithm of output prices and in the logarithm of log input prices remove only 14 percent of the variation in $\ln \left(w_{i t}\right)$ in the co-ops. Persistent differences across co-op mills in their reserve policies and debt repayments account for a large fraction of the variation in $\ln \left(w_{i t}\right)$ in these data. Hence, although some instrumental variable estimates will be reported, conventional least-squares will be the principal estimating method.

The point estimates in Table 3 of $\delta$, the (uncompensated) elasticity of working hours in co-ops with respect to their wages, are all negative. None is estimated precisely, however, so that a wide range of values is consistent with these data. Indeed, several of these estimates are not significantly different from zero by conventional criteria which would imply that a typical co-op maintained working hours virtually unchanged in the presence of shocks to net returns. Because conventional $F$ tests could not reject the hypothesis that, conditional on real wages, the year effects do not contribute significantly to the variation in the logarithm of working hours, the preferred single point estimates are those in rows 2 and 5 of Table 2 that control for correlated mill effects: these estimates are -0.175 and -0.103 .

The null hypothesis that $\delta$ is zero is not the only interesting special case. If $\delta$ were -1 , then a proportionate increase in hourly wages would leave annual earnings unchanged. In fact, by conventional criteria, almost all of the estimates of $\delta$ in Table 3 are significantly greater than -1 . While an increase in hourly earnings reduces annual hours of work, the decrease in annual work hours still leaves annual earnings higher: if $\delta$ is -0.103 (as in row 5 of Table 3), a ten percent increase in $w$ reduces annual work hours by one percent and raises annual earnings by nine percent.

The implications of the estimate of $\delta$ in row 5 of Table 3 for the familiar hours-wage supply function are drawn in Figure 4 in which, over the range of real wages observed in these data, working hours are relatively unresponsive to wages at high wages and low working hours and hours are more responsive to wages at low wages and long working hours. This mild convexity from below is

\footnotetext{
${ }^{19}$ As the error term in equation (8) incorporates variations in $\theta$ and as $\theta$ is involved in the wage-hours relation, equation (5), the concern about the correlation of wages with the disturbance in equation (8) is clear.
} 
embedded in the double-logarithmic formulation of equation (8), but it raises the question of whether such a nonlinear hours-wage relationship would be revealed in a specification that allowed for a more flexible relationship.

To address that question, the observations were separated into two regimes: one regime corresponds to hourly wages less than the median of $\$ 3.30$ and the second regime consists of observations with wages greater than $\$ 3.30$. Spline functions were estimated that allow the hourswages relationship at less than $\$ 3.30$ to differ from the hours-wage relation at greater than $\$ 3.30$.

Separate quadratic-in-wages equations were estimated to the observations in the two regimes subject to the constraints that the two quadratic equations meet at $\$ 3.30$, the knot, where they also have the same derivatives. Descriptive statistics on hours and wages in the two regimes are provided in Table 4 from which it is apparent that, at almost every point in the wage distribution, hours are lower in the higher wage regime than in the lower wage regime.

The equation estimated is a quadratic-in-wages spline:

$$
\begin{aligned}
H_{i t}=v_{i}+\left[a_{1}+\right. & \left.b_{1}\left(w_{i t}-w_{0}\right)+c_{1}\left(w_{i t}-w_{0}\right)^{2}\right] D_{1 i t} \\
& +\left[a_{2}+b_{2}\left(w_{i t}-w_{1}\right)+c_{2}\left(w_{i t}-w_{1}\right)^{2}\right] D_{2 i t}+u_{i t}
\end{aligned}
$$

where $D_{1 i t}$ takes the value of unity for observations where real wages are less than $\$ 3.30$ and of zero otherwise while $D_{2 i t}$ takes the value of unity for observations where real wages are greater than $\$ 3.30$ and of zero otherwise. $w_{0}$ is set to 1.62 , the lowest value observed and $w_{1}$ is the knot at $\$ 3.30$. Mill fixed effects are given by $v_{i}$ and $u_{i t}$ is a disturbance term assumed to be randomly distributed. The least-squares estimates of the parameters in equation (9) (namely, $a_{1}, b_{1}, c_{1}, a_{2}, b_{2}$, and $c_{2}$ ) are reported in Table 5 and Figure 5 draws the implied labor supply curve over the range of hourly wages observed.

The hours-wage relationship is negatively-sloped at relatively high and relatively low wages, but at between 2,000 and 2,100 hours (roughly 40 to 42 weekly hours) the relationship is close to vertical. In other words, at around 40 hours of work a week, changes in wages induce little change in working hours. ${ }^{20}$ Earlier in this section, attention was drawn to the fact that the coefficient of variation

\footnotetext{
${ }^{20}$ The presence of a fixed effect for each mill in estimating equation ( 9) implies that the precise range of hours over which the fitted labor supply curve exhibits little elasticity differs across mills. The curve drawn in Figure 5 is for a mill at about the central tendency for hours with as many mills with longer hours as mills with shorter hours.
} 
in hours in the co-ops was lower than that of employees in the conventional firms. The inelasticity of the estimated labor supply function of co-op workers at between 2,000 and 2,100 hours and where many hours observations are recorded ${ }^{21}$ helps account for this narrower dispersion in the hours of co-op workers.

The elasticities of hours with respect to hourly wages implied by the estimates of the quadratic spline, equation (9), are graphed in Figure 6: most are negative and most are greater than -1 , but at around 2,000 to 2,100 annual hours they gather around zero. ${ }^{22}$ The estimated elasticities from fitting equation (8) - values of -0.175 to -0.103 - are well within the range of values in Figure 6.

This discussion has centered on the point estimates. Figure 7 presents a 95 percent confidence interval around the fitted labor supply of equation (9). Although lines with many different slopes and shapes may be drawn within these confidence intervals, one that cannot be drawn over the range of observed wages is a vertical line nor, a fortiori, a positively-sloped line. ${ }^{23}$ Although a precise value has not been estimated, a negative hours-wage elasticity in worker co-ops appears to dominate. Is this plausible?

The Work Behavior of Other Self-Employed Workers

One way to answer this is to consult the research on the elasticity of hours with respect to wages for other self-employed workers. Fortunately, there have been a number of such studies in recent years. This work has been prompted by the suspicion that many employees work in conditions in which their opportunity to change their working hours in response to alterations in their returns to work is meagre and that self-employed workers have much more scope for varying their work hours. In

\footnotetext{
${ }^{21}$ Almost one-third of observations on hours in the co-ops are in the one hundred hours interval between 2,000 and 2,100.

${ }^{22}$ In part, the labor supply curve in Figure 5 resembles the shape that Berman (1967, p.229) conjectured. From close study of the plywood co-ops' behavior. Berman wrote, ......the short-run supply curve for hours of labor for shareholder-workers might take the shape of a vertical line at the fortyhour-weekly point (showing shareholders willing to work forty hours over a wide range of wage rates), positively inclined at the top at some point of high wages (shareholders willing to take advantage of prosperity to work longer hours at higher wages), and negatively inclined at the bottom at some point of low wages (shareholders willing to work longer hours as wages decline, to obtain adequate total compensation while keeping the company competitive on costs)."

${ }^{23}$ However, the hypothesis that the labor supply curve is vertical at wages above $\$ 3.30$ and negativelysloped at wages below $\$ 3.30$ cannot be rejected at conventional levels of significance.
} 
addition, instances in which employees have been presented with genuinely exogenous changes in wages to which they may adjust their hours of work have been hard to identify.

This has stimulated research on self-employed workers who face changes in the demand for their services that has given them the opportunity to alter their work behavior. This research has examined different dimensions of work such as whether the self-employed worker works for pay on a given day or when the worker stops paid work or how many hours the worker works. It is the last dimension of work - hours - that would provide the obvious comparison with these estimates of hours in the plywood co-ops.

There are several studies of the hours that taxi drivers work and, on this topic, the research of Ashenfelter, Doran, and Schaller (2010) most closely resembles the procedure in this paper. Their preferred estimate of the uncompensated elasticity of hours with respect to wages of New York taxidrivers is -0.23 with a relatively small estimated standard error. With far fewer observations than those available to Ashenfelter et al., the estimated elasticity in these plywood co-ops cannot claim to be estimated precisely though the finding of a dominant income effect appears to hold both for New York taxi drivers and for Pacific Northwest plywood co-op workers. ${ }^{24}$

Other empirical research on the hours worked of self-employed workers includes Boulier's (1979) analysis of non-salaried dentists. He found annual hours of these dentists were negatively related to the price of a tooth extraction, the elasticity being -0.049 . Using 1,456 observations on 286 self-employed men from the Panel Study of Income Dynamics, Parker, Belghitar, and Barmby (2005) report a negative elasticity of annual hours of work with respect to hourly wages of -0.234 though this becomes imprecise when the standard deviation of past wages is introduced into the fitted equation. All in all, the finding of a negative wage elasticity of working hours reported in this paper for the plywood co-ops is not out of line with wage elasticities estimated for other self-employed workers. Hours, Wages, and Changes in Mill Ownership

Finally, what does the hours of work equation estimated to the co-op observations imply about the hours worked of workers in the capitalist mills? This is not straightforward to answer because of the presence of mill-specific intercepts that account for the hours worked in each mill to be different

\footnotetext{
${ }^{24}$ Camerer, et al. (1997) also report a negative-inclined wage-hours relationship for taxi-drivers though Farber (2005) faults their instrumental variable procedure.
} 
from those worked in other mills. Conveniently, over this period, two mills converted from one form of organization to the other. Therefore, in two instances, hours and wages are observed for the mill as a co-op and hours and wages are observed for this same mill as a capitalist enterprise. One mill converted from a co-op to a capitalist enterprise ${ }^{25}$ and a second mill converted from a conventional mill to a co-op. ${ }^{26}$ In each case, the average wages and the average hours are calculated over the two years each was a co-op and over the adjacent two years when the mill operated as a conventional unionized plant. In each instance, estimates from fitting equation (9) to the coop mills are used as those values of hours that are "preferred" by the workers at these given wages. By how much do actual hours in the union mills diverge from those "preferred" at these wages where the implications of the estimates of equation (9) define those that are "preferred". The results are shown in Table 6.

When each mill operated as a capitalist workplace, the workers were covered by a region-wide collective bargaining agreement negotiated by the International Woodworkers of America and an association of employers. In one instance, substantially higher wages obtained relative to those in the co-op. Presumably, the higher wages reflect the effect of the union on wages in a bilateral monopoly setting. The collective bargaining agreement allowed for local differences in the terms of the agreement and the employers' association ensured that its members retained their "right to manage" (including their determination of working hours) in their plants.

In the top panel (PANEL A) of Table 6, the actual values of annual hours and real wages for Peninsula Plywood are recorded averaged over the two years when the mill is observed as a co-op (namely, 1968 and 1970) and over the adjacent two years (1972 and 1974) when the mill became a conventional firm covered by a collective bargaining agreement. Evidently, upon conversion from a co-op to a unionized mill, real wages changed negligibly but hours of work fell substantially. Because

\footnotetext{
${ }^{25}$ This mill was Peninsula Plywood Corporation of Port Angeles, Washington founded as a workers' co-op in 1941. It was sold to ITT Rayonier Inc. in April 1971. (The decision to sell was "opposed by many of the shareholders" although "a PenPly working share of $\$ 1,000$ in 1941 grew to be worth $\$ 300,000$ in 1971".) It operated as an affiliate of ITT Rayonier until 1989 when it became K Ply, after its acquisition by Klukwan, Inc. This closed in 2007. See Plywood Pioneers Association (2001) and accounts in the Peninsula Daily News online.

${ }^{26}$ This mill was Anacortes Veneer which opened in 1939 as a co-op. Subsequently, it was bought by the Forest Products division of the Times-Mirror Corporation. It converted back to a co-op in the 1980s before closing in 1992. Gunn (1986, pp. 347-8) mentions its reconversion.
} 
real wages changed little, the hours implied by the estimates of equation (9) also changed little but a large gap opened up between actual hours and preferred hours: at the wage of $\$ 3.723$ the plywood workers in the capitalist mill would have preferred to have worked more than 800 more hours than they did. It might be thought that this inference - that the workers in the capitalist mill would have preferred to work more hours at the given wage rate - is implausible. However, when the Current Population Survey has asked employees whether they would like to work the same or fewer or more hours at the same hourly wage, more than one quarter express a preference for more hours. See Golden and Gebreselassie (2007).

In the bottom panel (PANEL B) of Table 6, the actual values of annual hours and real wages for Anacortes are provided averaged over the last two years (1978 and 1980) when the mill was operated as a division of the Times-Mirror Corporation and over the first two years (1984 and 1986) when the mill reverted to a co-op. Evidently, real wages fell substantially in moving from a mill covered by a collective bargaining agreement to one not so covered but hours of work rose. In 1978 and 1980, when the mill was unionized and real wages high, the workers would have chosen to work fewer hours than they did (the gap between actual and predicted hours is 185). Upon becoming a co-op and selecting their work hours and their pay, the workers opted for lower hourly wages and longer hours. As a co-op, the gap between actual and preferred annual hours narrows to about a week's hours.

Therefore, on the assumption that the estimates of the hours-wage relationship fitted to the observations on the co-ops and reported in Table 5 represent the plywood workers' preferences (conditional upon real wages), there are large differences between the hours actually worked by employees in capitalist mills covered by a region-wide collective bargaining agreement and the hours they would prefer at these wages. Thus, the gaps between actual and preferred hours are smaller when each mill operates as a co-op and larger when each mill is a capitalist workplace. These gaps are greater in the capitalist workplace because the hours in the capitalist mills reflected the preferences of the owners and the management - and their demand for hours was negatively-related to the collectivelybargained wages. ${ }^{27}$ In the co-op mills, the negative relation between hours and wages in the coop plants reflected the preferences of the workers and a dominant income effect on hours of wage differences.

${ }^{27}$ On the demand for hours in capitalist mills, see the estimates in Pencavel and Craig (1994). 
I reiterate that the interpretation in the sub-section rests on the assumptions that the hours-wage relation estimated to observations on the co-op mills maps the plywood workers' work-income preferences and that these preferences remain unchanged when the workers are employed in conventional mills. If, on the contrary, when working in a mill they own and manage, the workers are less inimical to long hours than when working in a mill owned by those who supply the financial capital, the workers' preferences are organization-dependent. In this case, the shorter hours in the capitalist mills reflect, in part, the different attitudes to work when the workers are employed in the conventional mills.

\section{CONCLUSIONS}

The determination of working hours in cooperatives has been a neglected topic of empirical research in the literature on democratic firms. ${ }^{28}$ Yet, because the actions of worker co-ops reflect their preferred responses to shocks to their economic environments without being compromised by the preferences of a firm's capital owners and hired managers, the actions of worker co-ops offer an attractive setting to map the work-income preferences of workers. Workers in these co-ops set their work hours and the ultimate constraints on their actions were prices outside their influence.

Using different specifications and functional forms, the empirical work in this paper on the plywood cooperatives in the Pacific Northwest suggests that their hours and wages tend to be negatively associated implying the income effect of a wage increase exceeds the substitution effect. However, most estimates imply that an improvement in market conditions permitting an increase in hourly wages does not reduce annual hours of work sufficiently to cause a reduction in annual earnings. There is evidence of a vertical labor supply curve at hours around 40 hours a week. For those scholars engaged in research on labor supply, there is here a suggestion of an emerging empirical regularity: the labor supply functions of self-employed workers tend to be negatively-sloped with respect to their wages.

For scholars engaged in research on co-ops and attracted to Ward's hypothesis of the co-op's income per member-worker maximization, the imprecision of the estimates here allows these scholars

\footnotetext{
${ }^{28}$ Craig and Pencavel's (1993, p. 307) article on the objectives of worker cooperatives concluded "......that earnings, hours, and employment all enter the cooperatives' objectives." This result was arrived at through a different procedure from the more conventional one used in this paper. Nevertheless the conclusions of the two papers are not at variance.
} 
to retain their adherence to Ward's model. Scholars who find that Ward's focus on a monetary objective misses the important non-pecuniary benefits of the cooperative venture, the use of a utility function for the co-op that incorporates working hours and perhaps other aspects of work may be a welcome development that is amenable to further empirical application.

During the period of analysis, two mills converted from one type of ownership to another and this allows for the examination of the change in hours of work in the same plant when the identity of the owners switches between those who supply labor and those who supply capital. In both instances, working hours are lower when the mill is owned by those who supply the capital than when the mill is owned by the rank-and-file workers in the plant. When these mills were conventional capitalist workplaces, the employees were covered by a multi-employer collective bargaining agreement and the hours of work are those chosen by management in response to the wage specified in the unionmanagement contract. To the capitalist management, the hourly wage is a cost whose effects on the owners' net revenues can be moderated by cutting hours of work; to the worker co-op, the hourly wage is a factor in a worker's income and the effects on his income can be enhanced by working longer hours. The wage plays a different role in the objectives of the two ownership forms.

This illustrates the important and long-acknowledged point that the interpretation of the hourswage relation requires attention to the issue of identification: is this a demand function or a supply function or neither? In the case here, with observations at the workplace level, the identification problem is resolved by specifying the decision-makers: the member-workers in the co-op mill and the capital owner-managers in the capitalist mill. In other cases, the decision-makers may not be so clearly determined. 


\section{REFERENCES}

Ashenfelter, Orley, Doran, Kirk, Schaller,Bruce, 2010. A shred of credible evidence on the long-run elasticity of labour supply. Economica, 77 (308), 637-50.

Berman, K. V., 1967. Worker-Owned Plywood Companies: An Economic Analysis, Washington State Univ. Press, Pullman, WA.

Berman, K.V., Berman, M.D., 1978. The long-run analysis of the labor-managed firm: A comment, American Economic Review, 68(4), 701-05.

Berman, M. D., 1977. Short-Run efficiency in the labor-managed firm. Journal of Comparative Economics, 1, 309-14.

Boulier, Bryan L., 1979. Supply decisions of self-employed professionals: The case of dentists, Southern Economic Journal, 45(3), 892-902.

Burdín, Gabriel, Dean, Andrés., 2012. Revisiting the objectives of worker-managed firms: An empirical assessment. Economic Systems, 36, 158-71.

Camerer, Colin, Babcock, Linda, Loewenstein, George, Thaler, Richard, 1997. Labor supply of New York City cabdrivers: One day at a time. Quarterly Journal of Economics, 112(2), 407-41. 
Carrington, William J., McCue, Kristin, Pierce, Brooks, 1996. The role of employer/employee interactions in labor market cycles: Evidence from the self-employed. Journal of Labor Economics, $14(4), 571-602$.

Craig, Ben, Pencavel, John, 1992. The behavior of worker cooperatives: The plywood companies of the Pacific Northwest. American Economic Review, 82(5), 1083-1105.

Craig, Ben, Pencavel, John. 1993. The objectives of worker cooperatives. Journal of Comparative Economics, 17, 288-308.

Defourny, Jacques, Lovell, C.A.Knox, N’Gbo, Aké G.M., 1992. Variation in productive efficiency in French workers' cooperatives. The Journal of Productivity Analysis, 3(1-2), 103-117.

Fakhfakh, Fathi, Pérotin, Virginie, Gago, Mónica, 2012. Productivity, capital, and labor in labormanaged and conventional firms: An investigation on French data. Industrial and Labor Relations Review, 65 (4), 847-79.

Farber, Henry S., 2005. Is tomorrow another day? The labor supply of New York City cabdrivers. Journal of Political Economy, 113 (1), 46-82.

Golden, Lonnie, and Gebreselassie, Tesfayi, 2007. Overemployment mismatches: the preferences for fewer work hours. Monthly Labor Review, 4 , 18-36. 
Gunn, Christopher E., 1980. Plywood co-operatives of the Pacific Northwest: Lessons for workers' self-management in the United States. Economic Analysis and Workers' Management, 14 (3),393-416.

Gunn, Christopher E., 1986. Workers’ Self-Management in the United States: Contemporary Cases and Comment. Economic Analysis and Workers’ Management, 20(4),338-56.

Houthakker, H.S., 1960. Additive preferences. Econometrica, 28(2), 244-57.

Jones, Derek C., 2007. The productive efficiency of Italian producer cooperatives: Evidence from conventional and cooperative firms. In: Novkovic, Sonja, Sena,Vania (Eds.), Cooperative Firms in Global Markets. Advances in the Economic Analysis of Participatory \& Labor-Managed Firms. Emerald Group Publishing Limited. 10. pp. 3-28.

Keane, Michael P., 2011. Labor supply and taxes: A survey. Journal of Economic Literature, 49(4), $961-1075$

Oregon Forest Resources Institute. 2012. An Economic Assessment of Oregon's Forest and Wood Products Manufacturing Sector. The 2012 Forest Report. July 31.

Parker, Simon C., Belghitar, Yacine, Barmby,Tim. 2005. Wage uncertainty and the labour supply of self-employed workers. The Economic Journal. 115(502). Conference Papers. C190-C207. 
Pencavel, John, Craig, Ben, 1994. The empirical performance of orthodox models of the firm: Conventional firms and worker cooperatives. Journal of Political Economy. 102(4), 718-44.

Plywood Pioneers Association. 2001. From Penply to Kply: The History of Peninsula Plywood Corporation and its Successors, No. 23 in a series of monographs on the history of plywood manufacturing.

Scitovsky, Tibor . 1943. A note on profit maximization and its implications. Review of Economic Studies. 11(1), 57-60.

Ward, Ben, 1958. The firm in Illyria: Market syndicalism. American Economic Review. 48(4), 566-89. 
Table 1

Characteristics of the Eleven Plywood Co-operatives in Washington State Used in this Study

\begin{tabular}{|c|c|c|c|c|c|c|c|}
\hline \multirow[t]{2}{*}{ name } & \multicolumn{3}{|c|}{ year } & \multirow{2}{*}{$\begin{array}{l}\text { capacity } \\
\text { in } \\
\text { million } \\
\text { sq. ft. }\end{array}$} & \multicolumn{3}{|c|}{ number of } \\
\hline & $\begin{array}{l}\text { started as } \\
\text { a co-op }\end{array}$ & $\begin{array}{l}\text { plant } \\
\text { built }\end{array}$ & $\begin{array}{l}\text { closed as a } \\
\text { co-op }\end{array}$ & & lathes & driers & presses \\
\hline North Pacific & 1949 & 1921 & $?$ & 55 & 1 & 3 & 2 \\
\hline Peninsula & 1941 & 1941 & 1971 & 96 & 2 & 3 & 3 \\
\hline Anacortes & 1939 & 1939 & 1992 & 128 & 2 & 3 & 3 \\
\hline Buffelen & 1955 & 1916 & 1991 & 50 & 2 & 3 & 4 \\
\hline Everett & 1951 & 1923 & $?$ & 125 & 2 & 4 & 3 \\
\hline Puget Sound & 1942 & 1942 & $?$ & 120 & 2 & 3 & 2 \\
\hline Fort Vancouver & 1955 & 1928 & 1996 & 125 & 2 & 4 & 3 \\
\hline Hardel Mutual & 1952 & 1947 & still open & 39 & 1 & 2 & 2 \\
\hline Hoquiam & 1955 & 1947 & 2012 & 36 & 1 & 1 & 1 \\
\hline Stevenson Co-Ply & 1955 & 1949 & 1992 & 60 & 2 & 2 & 1 \\
\hline Mt. Baker & 1950 & 1950 & 1992 & 60 & 2 & 2 & 2 \\
\hline
\end{tabular}

Most of this information is drawn from Appendix A of Berman (1967) and describes these mills in 1964. The conversion of a conventional mill to a co-op is indicated when the year of "plant built" differs from the year "started as a co-op". The entry "?" means that information could not be found to specify the year the mill closed. Buffelen stopped producing plywood in 1991 and now specializes in doors. 
Table 2

Descriptive Statistics on Annual Hours of Work and Real Hourly Wages in Worker Co-ops and in Conventional Mills

\begin{tabular}{|l|c|c|c|c|}
\hline & \multicolumn{2}{|c|}{ Coop mills } & \multicolumn{2}{c|}{$\begin{array}{c}\text { Conventional unionized } \\
\text { mills }\end{array}$} \\
\hline & annual hours & real wages & annual hours & real wages \\
\hline minimum & 1.232 & 1.628 & 0.864 & 1.030 \\
\hline $25^{\text {th }}$ percentile & 1.960 & 2.947 & 1.758 & 3.691 \\
\hline median & 2.048 & 3.299 & 1.912 & 4.132 \\
\hline mean & 2.086 & 3.361 & 1.860 & 4.364 \\
\hline $75^{\text {th }}$ percentile & 2.265 & 3.781 & 2.000 & 4.758 \\
\hline maximum & 2.920 & 5.371 & 2.840 & 10.031 \\
\hline coefficient of variation & 0.145 & 0.209 & 0.158 & 0.269 \\
\hline
\end{tabular}

Hours are expressed in thousands of annual hours and wages in 1967 dollars. 
Table 3

Estimates of $\delta$ in Equation (8) Fitted to 55 Mill-Year Observations on Worker Co-ops

\begin{tabular}{|l|l|c|c|}
\hline row & & Point estimate (standard error) of $\delta$ & $R^{2}$ \\
\hline 1 & OLS excl. mill \& year fixed effects & $-0.086(0.076)$ & 0.016 \\
\hline 2 & OLS incl. mill fixed effects & $-0.175(0.061)$ & 0.424 \\
\hline 3 & OLS incl. mill \& year fixed effects & $-0.259(0.115)$ & 0.559 \\
\hline 4 & INV excl. mill \& year fixed effects & $-0.006(0.106)$ & \\
\hline 5 & INV incl. mill fixed effects & $-0.103(0.113)$ & \\
\hline 6 & INV incl. mill \& year fixed effects & $-0.374(0.369)$ & \\
\hline
\end{tabular}

Heteroskedastic-consistent estimated standard errors are in parentheses. 
Table 4

Descriptive Statistics on Annual Hours and Hourly Real Wages for Observations in the Lower Wage

Regime $(<\$ 3.30)$ and in the Higher Wage Regime $(>\$ 3.30)$

\begin{tabular}{|l|c|c|c|c|}
\hline & \multicolumn{2}{|c|}{ Real Wages $<\$ 3.30$} & \multicolumn{2}{c|}{ Real Wages $>\$ 3.30$} \\
\hline number of observations & \multicolumn{2}{|c|}{27} & hours & wages \\
\hline & hours & wages & 2.054 & 3.900 \\
\hline mean, $\mu$ & 2.120 & 2.815 & 2.040 & 3.782 \\
\hline median, $M$ & 2.088 & 2.935 & 1.976 & 3.564 \\
\hline $1^{\text {st }}$ quartile, $Q_{1}$ & 1.952 & 2.652 & 2.164 & 4.179 \\
\hline $3^{\text {rd }}$ quartile, $Q_{3}$ & 2.400 & 3.149 & 1.512 & 3.305 \\
\hline minimum & 1.232 & 1.628 & 2.568 & 5.371 \\
\hline maximum & 2.920 & 3.293 & 0.212 & 0.476 \\
\hline standard deviation, $\sigma$ & 0.377 & 0.437 & 0.103 & 0.122 \\
\hline$\sigma / \mu$ & 0.178 & 0.155 & 0.046 & 0.081 \\
\hline$\left[1 / 2\left(Q_{3}-Q_{1}\right)\right] \div M$ & 0.107 & 0.085 & & \\
\hline
\end{tabular}

Hours are expressed in thousands of annual hours and hourly wages in 1967 dollars. 
Table 5

Least-Squares Estimates of the Coefficients (and Estimated Standard Errors in Parentheses) of the Quadratic-in-Wages Spline Function

\begin{tabular}{|c|c|c|c|}
\hline \multicolumn{4}{|c|}{ Least-Squares Estimates of Equation (9) } \\
\hline parameters & estimate & parameters & estimate \\
\hline \multicolumn{2}{|c|}{$<\$ 3.30$ regime } & \multicolumn{2}{|c|}{ > \$3.30 regime } \\
\hline$a_{1}$ & $2.676(0.248)$ & $a_{2}$ & $2.063(0.080)$ \\
\hline$b_{1}$ & $-0.856(0.361)$ & $b_{2}$ & $0.127(0.144)$ \\
\hline$c_{1}$ & $0.293(0.139)$ & $c_{2}$ & $-0.137(0.103)$ \\
\hline
\end{tabular}


Table 6

Average Hourly Real Wages and Annual Hours Worked (Actual and Implied) for Two Mills that Changed Their Ownership Structure

\begin{tabular}{|c|c|c|c|c|}
\hline \multicolumn{5}{|c|}{ PANEL A } \\
mill as & observed average & observed average & preferred hours & observed minus \\
a.... & real hourly & work hours & given wages & preferred hours \\
& earnings & & & \\
\hline$\ldots$. co-op & $\$ 3.734$ & 2,580 & 2,621 & -41 \\
\hline ..capitalist & $\$ 3.723$ & 1,804 & 2,622 & -816 \\
\hline difference & $\$ 0.011$ & 850 & -1 & 775 \\
\hline
\end{tabular}

In PANEL A, the observed values for the co-op are the average of the years 1968 and 1970. The observed values for the capitalist mill are the average of 1972 and 1974 . The line "difference" means the co-op value minus the capitalist value.

\begin{tabular}{|c|c|c|c|c|}
\hline \multicolumn{2}{|c|}{ PANEL B } & Anacortes Veneer \\
\hline mill as & observed average & observed average & preferred hours & observed minus \\
& real hourly & work hours & given wages & preferred hours \\
& earnings & & & \\
\hline$\ldots$. co-op & $\$ 2.201$ & 1,808 & 1,766 & 42 \\
\hline ...capitalist & $\$ 4.489$ & 1,700 & 1,515 & 185 \\
\hline difference & $-\$ 2.288$ & 108 & 251 & -143 \\
\hline
\end{tabular}

In PANEL B, the observed values for the co-op are the average of the years 1984 and 1986. The observed values for the capitalist mill are the average of 1978 and 1980 . Observations for 1982 are unavailable. The line "difference" means the co-op value minus the capitalist value. 
Figure 1

Softwood Structural Panel Board Production: Percent of Total U.S. Production of Plywood from Washington and Oregon and from Southern States, 1964-2011

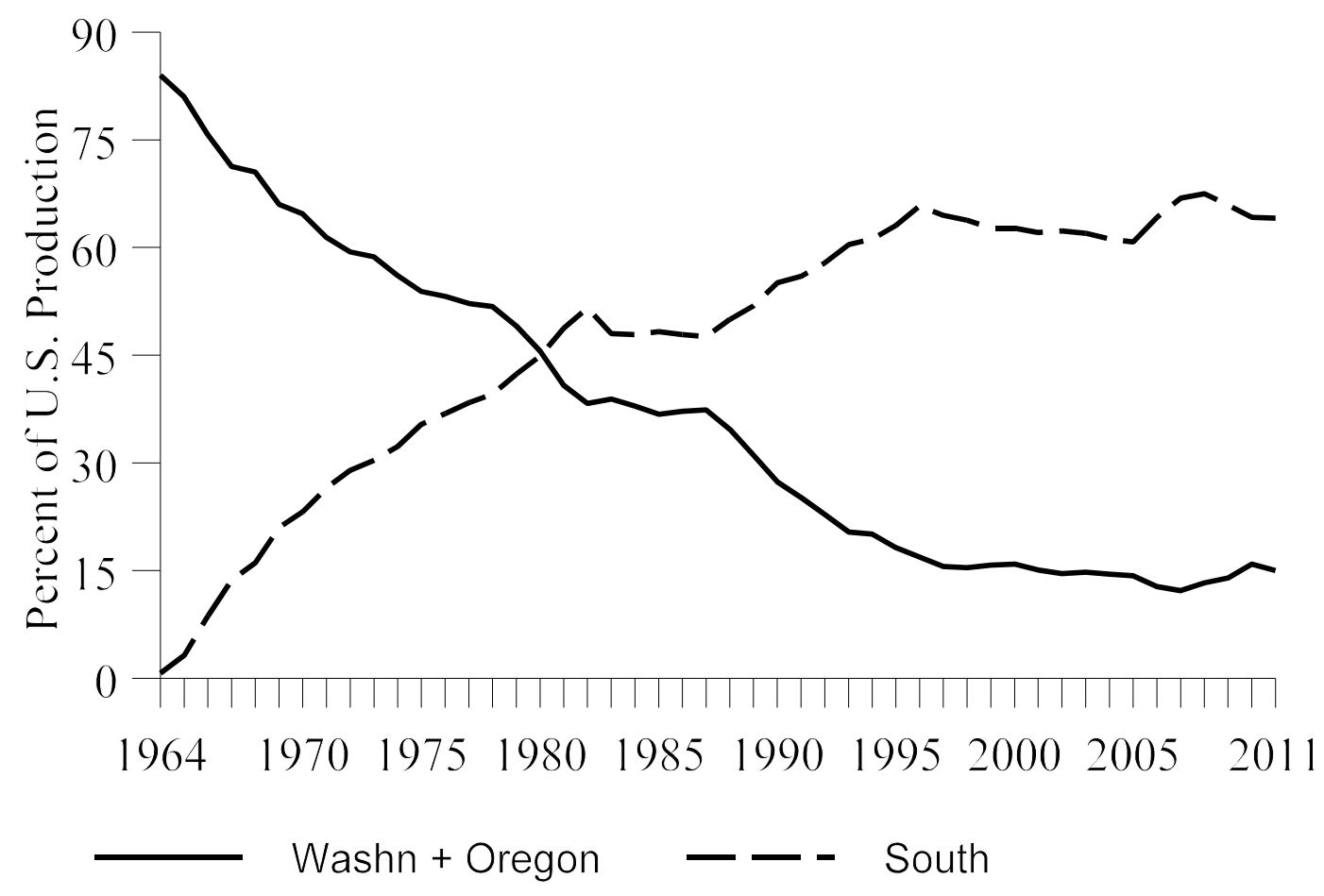

Softwood structural panel board production includes plywood, waferboard and oriented strand board. The Southern States are Alabama, Arkansas, Florida, Georgia, Louisiana, Maryland, Mississippi, North Carolina, South Carolina, Texas, Virginia, and West Virginia. From U.S. Forest Service, Pacific Northwest Research Station, Production, Prices, Employment, and Trade in Northwest Forest Industries All Years, http://www.fs.fed.us/pnw/ppet/ 
Figure 2

Ward's Proposed Optimal Employment of the Worker Co-op

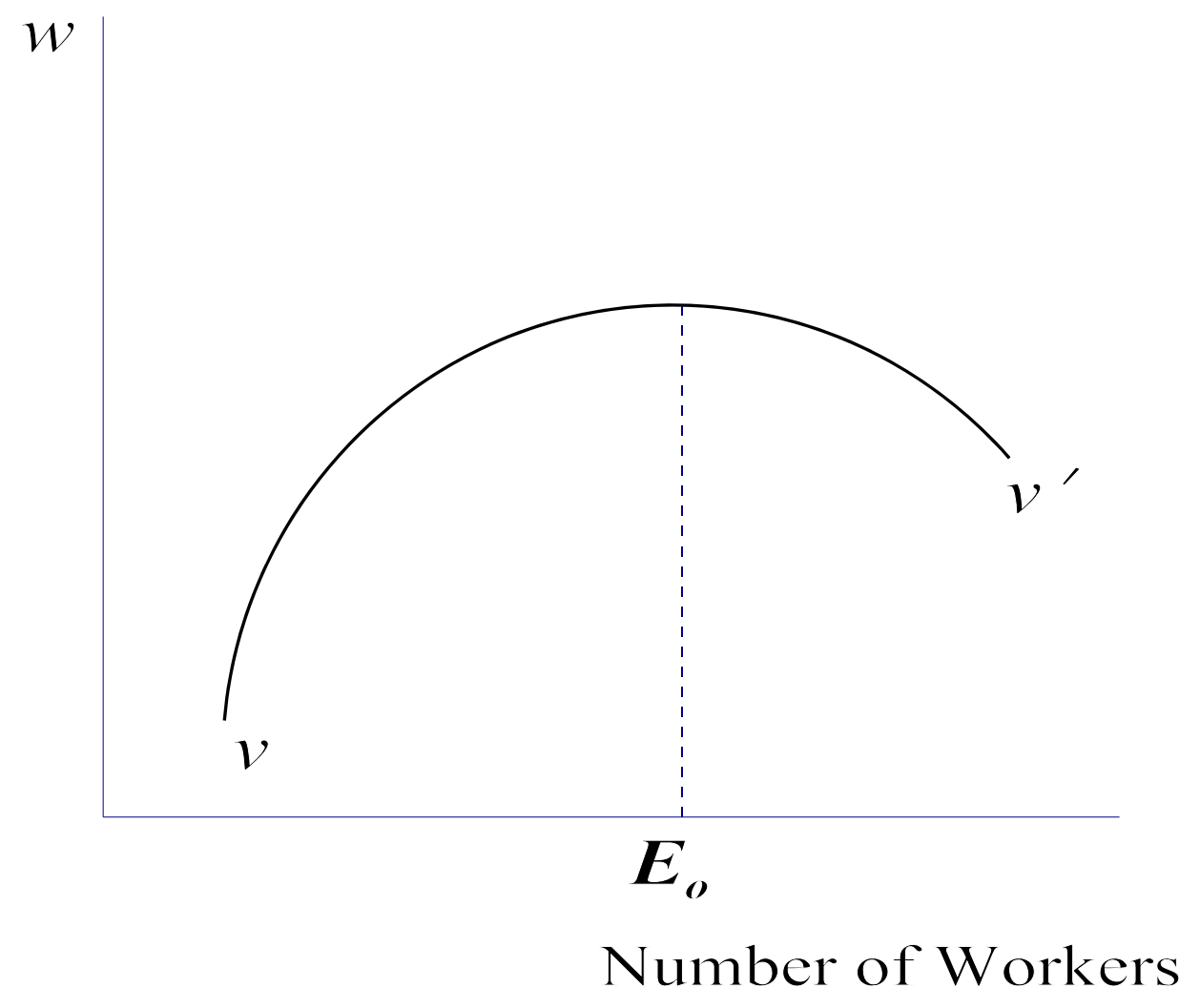


Figure 3

A Worker Co-op's Utility Maximizing Choice of Hours

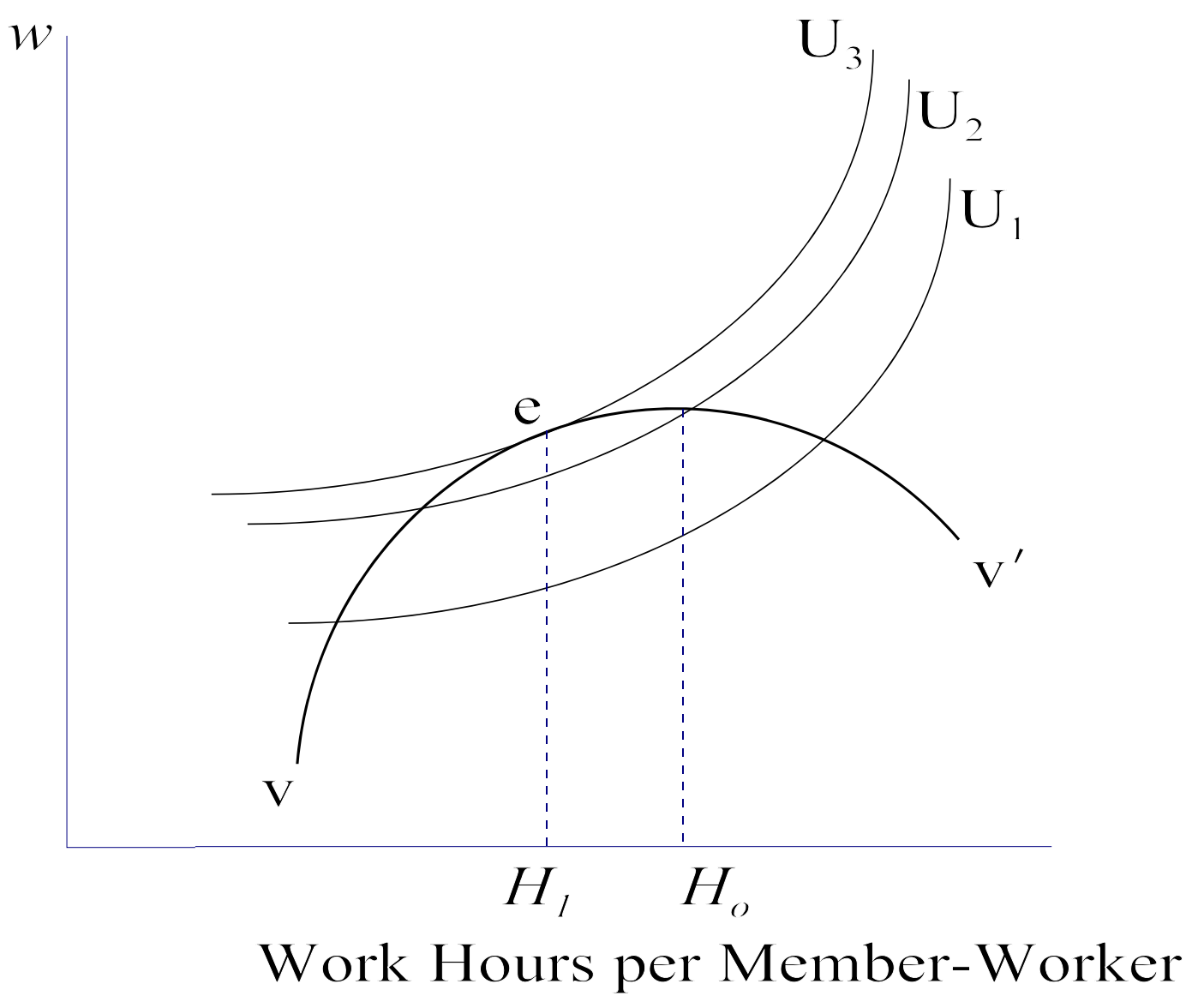

Notes to Figure 3: $\mathrm{U}_{1}, \mathrm{U}_{2}$ and $\mathrm{U}_{3}$ are indifference curves between hourly earnings and working hours such that $U_{3}$ is preferred to $U_{2}$ which, in turn, is preferred to $U_{1} \cdot H_{0}$ denotes the hours of work per worker that maximizes net returns per worker but, given work preferences, these hours are too long and the co-op's members prefer shorter working hours of $\mathrm{H}_{1}$ even though their take-home pay is lower. 
Figure 4

Labor Supply Curve of Worker Co-ops Implied by the Estimates in Row 5 of Table 3

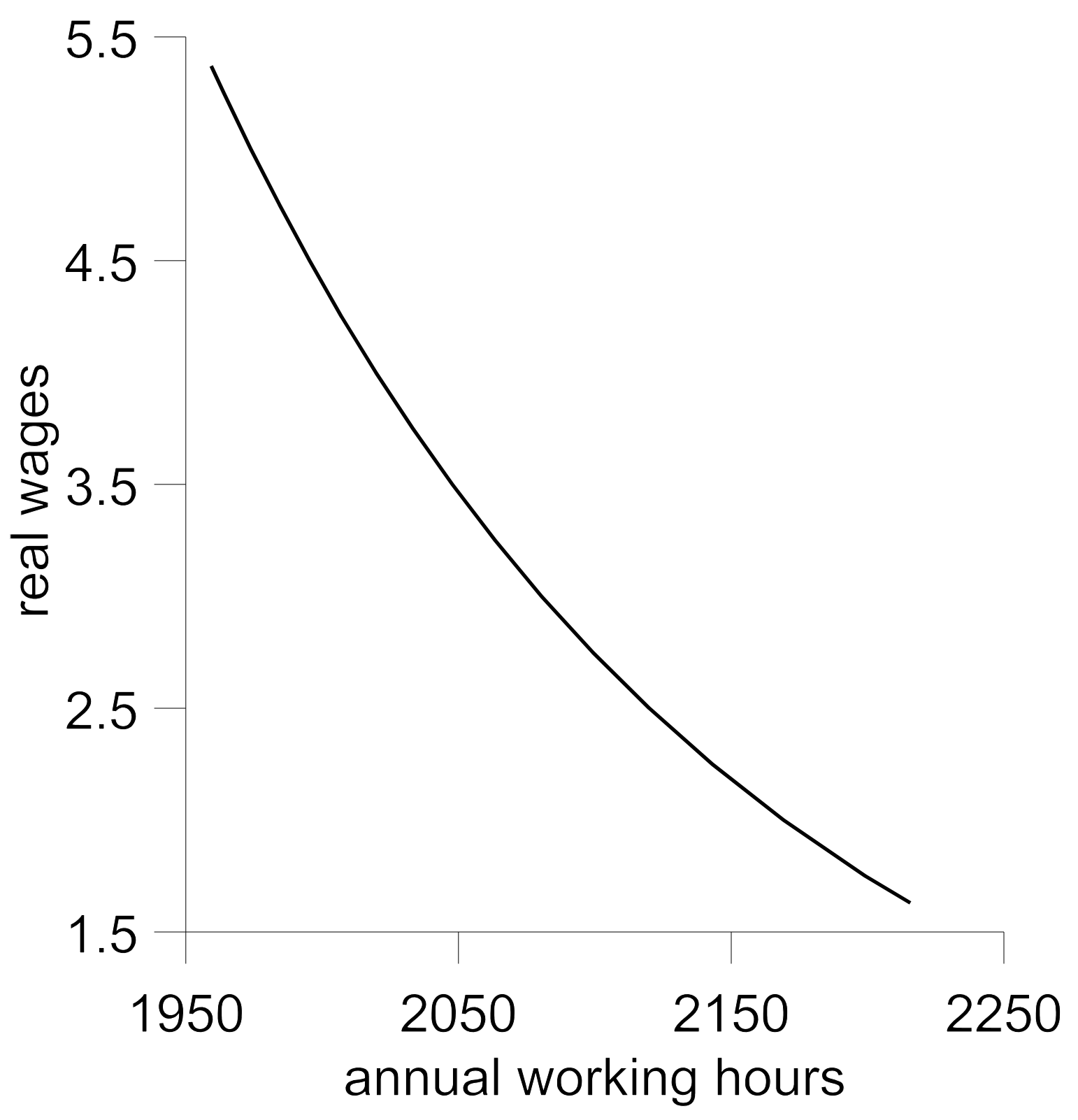


Figure 5

Labor Supply Curve of Worker Co-ops as Implied by the Fitted Quadratic-in-Wages Spline

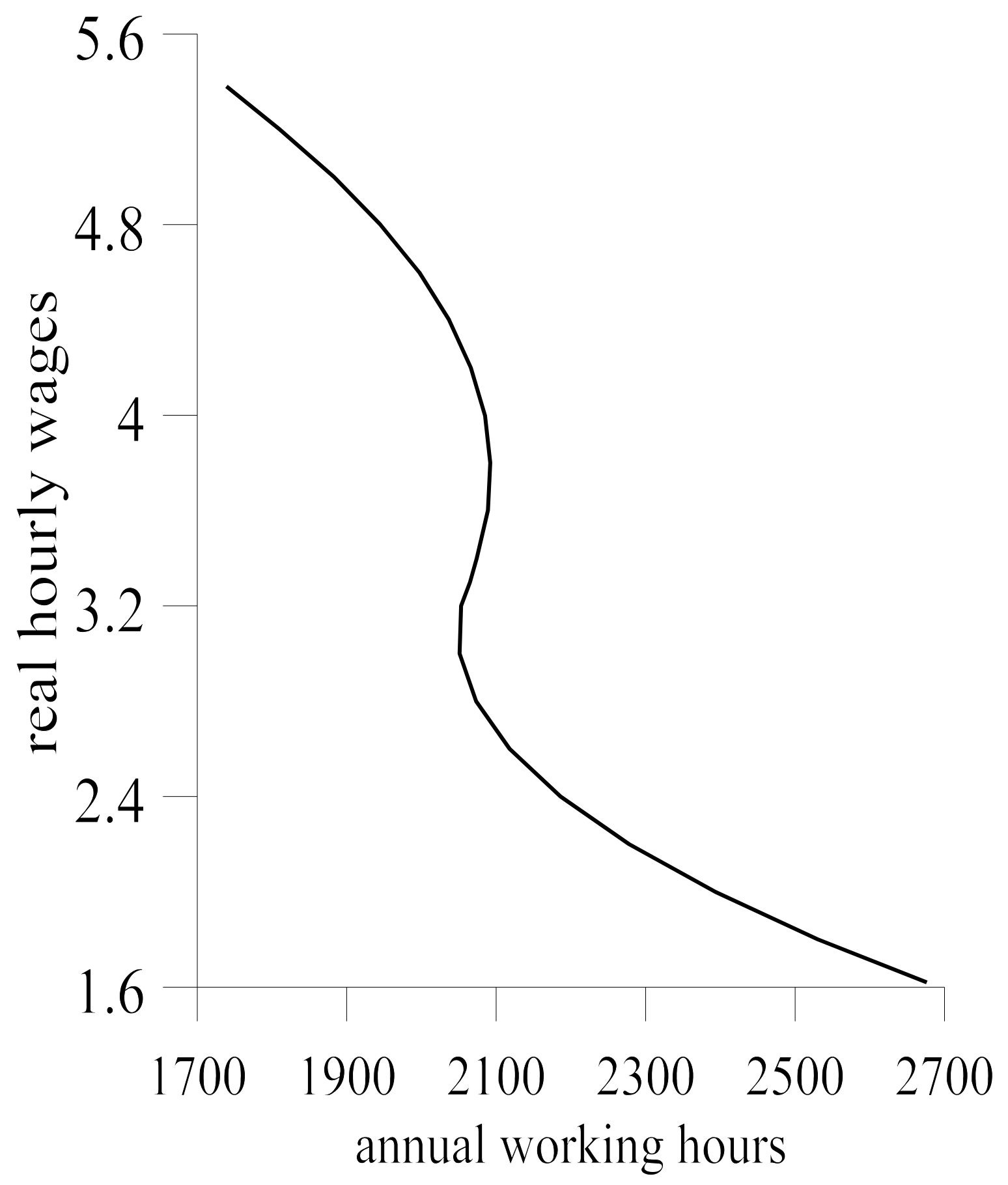


Figure 6

Elasticity of Hours of Work with respect to Wages Evaluated at Different Points on the Labor Supply Curve Implied by the Quadratic-in-Wages Spline Estimates

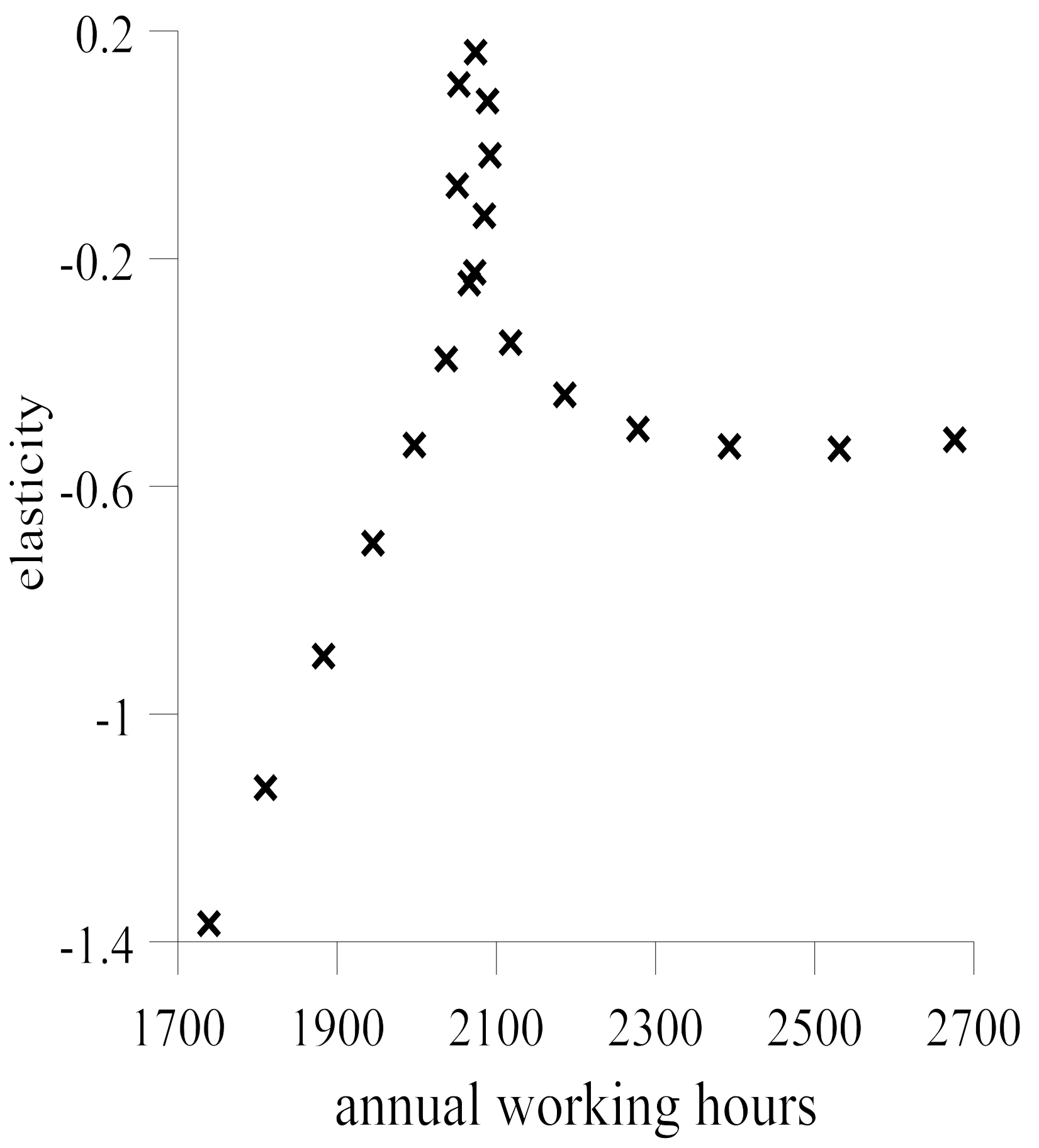


Figure 7

Ninety-Five Percent Confidence Intervals around the Labor Supply Curve of Worker Co-ops from the Implied Quadratic-in-Wages Spline

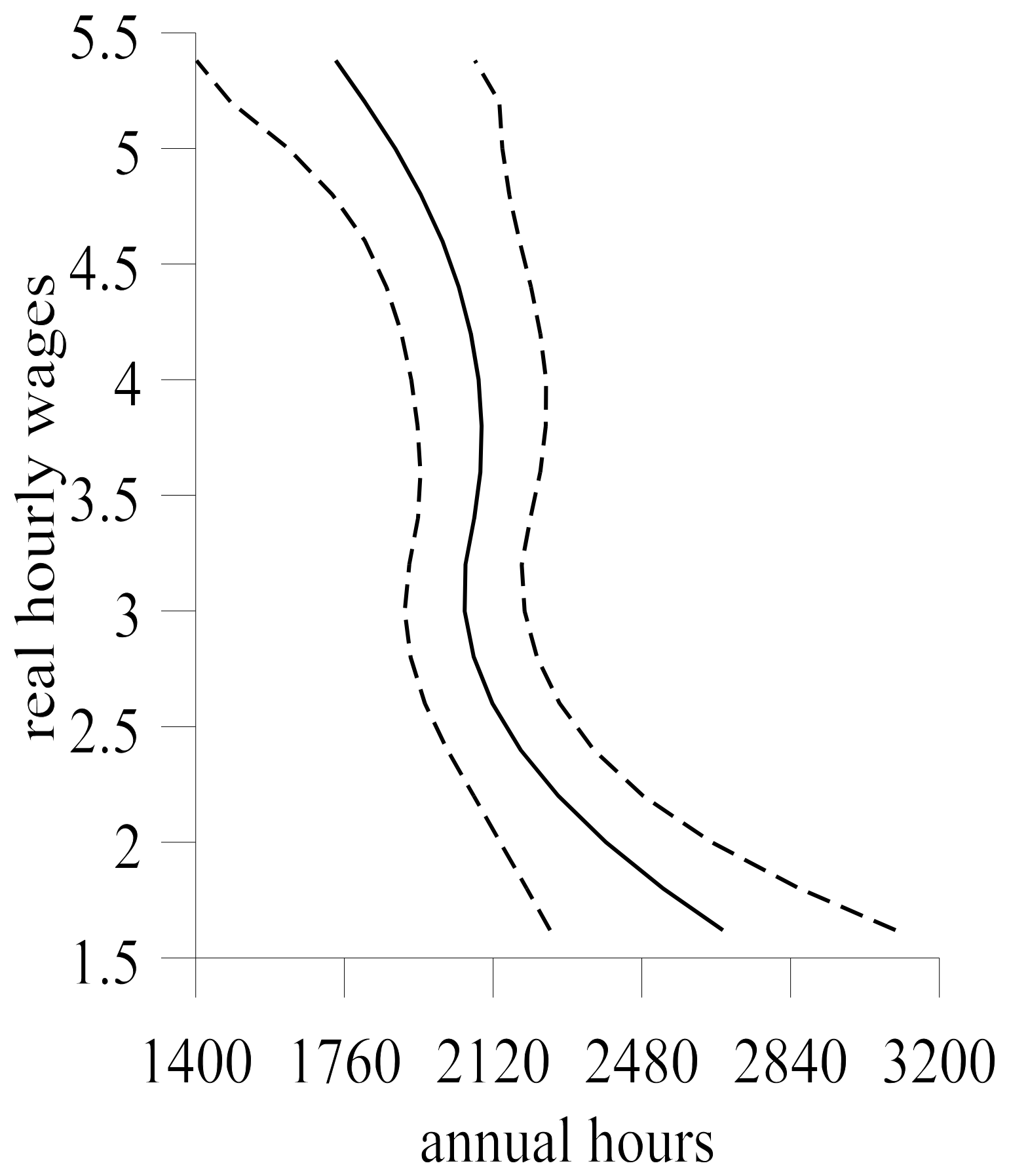

